\title{
Notes on Ornithodoros rostratus, brasiliensis and turicata (")
}

\author{
by \\ DR. HENRIQUE DE BEAUREPAIRE ARAGAO \\ (Chief in Service) \\ (With plate $\mathrm{XXXI}$ )
}

In 1911, we published a description of Ornithodoros rostratus based upon numerous specimens of this species coming from the State of Matto Grosso. It was a very characteristic species amongst those up to that time described, and therefore we had no hesitation in considering it as a new one.

In 1917, Barbara and Dios (1) studied a species sent to them by Dr. Migone from Porto Martinho, State of Matto Grosso, and they had no doubts about identifying it with Ornithodoros turicata, and considered the $O$. rostratus as being identical with $O$. turicata.

Based upon the comparison of the specimens of both species we possessed and upon the description of same, we then published a work showing that such a confusion should not be possible ( 2 ).

Thus the matter stood when I received, in 1922, from Rio Grande do Sul a new Ornithodoros, much resembling $O$. rostratus, but also different enough from the latter, especially on account of the organization of the tarsi.

In view of the morphological differences of this species, we had no doubts about considering it as a new one and we described it under the name of Ornithodoros brasiliensis.

The description and drawings published by Barbara and Dios concerning the species which they identified with that of $O$. rostratus and $O$. turicata conducing to their synonymy, make us suppose, the species in the authors' possession and which they classified as being O. turicata was just the same as that later described by us (3) under the name of Ornithodoros brasiliensis judging from the shape of the body and the appearance of the tarsi.

(*) Received for publication 14 April, 1931. 
In spite of the works above cited, Dios and Ruopoff, in their late work (4) still consider the Ornithodoros coming from Jujuhy and of which they recently came into possession, as being specimens of $O$. turicata (O. rostratus) and which, in our opinion, might perhaps be our $O$. brasiliensis.

In order to dispel the doubts now existing about such Ornithodoros, we are going to give, as follows, the description of the 3 species: O. rostratus, $O$. brasiliensis and $O$. turicata, so that their differences shall be brought into plain evidence, thus avoiding the present state of uncertainty with respect to these ticks.

For a greater elucidation of the matter, we also present drawings of the dorsal surface of the body of the 3 species and of the 1-st and 4-th tarsi of each of them, thus further facilitating their distinction one from another.

\section{Ornithodoros rostratus Aragão, 1911.}

Female specimen (fig. 1). Body a little narrow, tapering at the anterior extremity on account of the camerostome which is salient, measuring $8,4 \mathrm{~mm}$. in length by $3,4 \mathrm{~mm}$. in breadth. Integument of a dark leaden colour, covered by very numerous mammillae of a clearer tint and of a rather regular size. On the dorsum, there are 12 to 15 various areas where the mammillae are very small and disposed in crossing lines, thus enclosing small spaces almost rectangular; these areas are larger and very clear at the posterior part of thedorsum. Long, fine and numerous hairs, implanted on mammillae spread over the whole dorsal surface of the animal.

The ventral surface is of a clearer tint than the dorsal, being likewise hairy and covered by mammillae. Circular, prominent peritremes. Deep prae-and post-anal, genital and anomarginal grooves.

The genital opening of the female is semilunar in shape, being situated at the level of the space which separates the two first coxa; the genital orifice of the male is small and of a circular contour.

In the specimens we had in our possession and all preserved in a dry state, we were not able to observe any existence of eyes.

Rostrum not wrapt by the camerostome, but barely covered by the latter. The camerostome exceeding the border of the body by $0,40 \mathrm{~mm}$. in extension, presents in that portion a triangular shape and exhibits numerous hairs implanted on the borders. Long palps, with articles decreasing in size progressively until the 3-rd; the 4-th is a little larger than the preceding, being conical in shape and hairy.

Long legs, not wrinkled in all the pairs. Coxa progressively decreasing in size contiguous. Tarsus of the 1-st pair supplied with two points on the dorsal surface, fig. 1a: a sharp one, at its beginning turned slightly towards the extremity; the other, á short one, of a similar arrangement at the distal extremity. As to the fourth pair, there only subsists the salience of the extreme end of the larsus (fig. 1b). 
Description taken from numerous specimens, preserved in dry state, caught on the banks of the river Guaporé, State of Matto Grosso, by the chemist Cezar Diogo.-- (Aragão H. B.-Memorias do Instituto Oswaldo Cruz, 1911 T. 3, Fasc. 2, pg. 166).

\section{Ornithodoros brasiliensis Aragão, 1923.}

Female specimen (fig. 2), measuring $10,5 \mathrm{~mm}$. in length by $6 \mathrm{~mm}$. in breadth. The male is smaller, measuring, when fully developed, $6 \mathrm{~mm}$. in length by $3,5 \mathrm{~mm}$. in breadth. Elliptical body with camerostome visible on the dorsal surface. Integument of a dark leaden colour, covered by numerous mammillae of a rather irregular size. On the dorsal surface, there are 12 to 15 areas with very small mammillae. These areas are larger on the posterior part of the dorsal surface. Fine and relatively numerous hairs implanted on the whole dorsal surface,

Ventral surface of a clearer tint than the dorsal one and likewise hairv and covered by mammiliae. Circular, salient peritremes, situated above the intercoxal space. No eyes. Rostrum not wrapt by the camerostome and barely covered by the latter. The camerostome exceeds the border of the body by 0,10 millimetres, having a sub-triangular shape and numerous hairs. Palps progressively decreasing in size until the 3-rd article; the 4 - 1 h article is a little longer than the 3 -rd, presenting a conical shape.

Long legs; coxa progressively decreasing and contiguous; tarsus of the 1-st pair provided by a small point at the distal extremity and by 3 rugosities on the dorsal border (fig. 2a). These rugosities grow less on the tarsi of the and and 3rd pairs, being absolutely lacking on the 4-th tarsus, which is smooth, only barely presenting a small point at the distal part (fig. 2b).

Description of numerous specimens, sent from S. Francisco de Paula, State of Rio Grande do Sul, by Sr. Napoleão de Moura, to whom we render here our thanks for the courtesy and interest he showed in facilitating our study of this tick. (Aragão H. B. Brasil Medico, Vol. 37, 1923, pg. 20) Rio de Janeiro, April 12-th, 1931.

\section{Ornithodoros turicata (Dugés, 1876 ,}

Argas turicata Alf. Dugés, 1876.

Ornithodoros americanus G. Marx, 1895.

«Description (fig. 3)-Corps à bords latéraux droits ou presque droits, parallèles, à extrémité antérieure rétrécie en pointe arrondie ct plus ou moins dépassée (à l'état de réplétion) par la partie antérieurc du rostre, à bord postérieur largement arrondi; jaune terreux, et déprimé à jeun brun violacé et renflé souvent presque aussi épais que large à l'état de répletion; pattes toujour plus claires. La face dorsale est limilée à jeun par un rebord large, saillant, semblable au reste du tégument, plus élroit et plus saillant, en avant; une saillie très antérieure; un large sillon trans versal un peu en avant du milieu, à extrémités infléchies en arrière; un autre large sillon parallèle au bord postérieur, dont il est très rapproché; 
une courte dépression mediane, à peu près à égale distance des deux sillons; en avant de celle-ci, deux dépressions latérales, allongées, divergentés en arrière, et deux autres courtes, parallèles aux bords latéraux et rejoignant plus ou moins nettement le sillon transverse postérieur. A l'état de répletion, la surface est très convexe et ne présente que la trace de ces diverses dépressions. A la face ventrale, un sillon pre-anal qui rejoint les sillons sus-coxaux; un sillon post-anal, parallèle au précédant, à égale distance de l'anus et du bord postérieur; un sillon anal dépassant le sillon post-anal et s'étendant jusqu'au bord postérieur; plis sus-coxaux et coxaux bien marqués, ces dernièrs ne dépassant pas la seconde paire de hanches. A l'état de replétion, la plupart de ces détails sont effacés et les sillons sont reduits à des dépressions linéaires, sauf le sillon post-anal et les extrémités du sillon pré-anal, qui restent relativement profonde. Stigmates à la face dorsale des plis sus-coxaux, circulaires, larges de 180 à 200 micra à fente semi-lunaire. Anus presque aussi large que long, pourvu de nombreusses soies; cadre anal presque quadrangulaire, large de 225 micra. Pas d'yeux.

Tégument épais coriace, à granulations hémispheriques, brillantes, contigues, plus larges dans la partie postérieure que dans la partie antérieure, de 75 à 120 micra de diamétre, formant par leur ensemble un réseau à mailles irréguliérement polygonales, limitées par des plis plissés, et dont le centre est formé d'un épaississement chitineux, brun, saillant, qui porte tantôt une à six pointes mousses, tantôt un poil en massue, quelquefois une soie aigue ou mousses, tantôt un poil en massue, quelquefois une soie aigue ou mousse. Entre ces mailles sont préparties des fossettes réticulées, homologues de celles des Argas semblables á celles d'O. Savignyi, symetriques à situation constante; à la face dorsale, elles occupent les dépressions, sauf le si lon périphérique; à la face ventrale, des sillons anal et pré-anal; le sillon post-anal est formé de plis très fins, perpendiculares à sa direction, Rostre à base recouverte par un tégument très finement gaufré; long de 500 micra (male) á 650 micra (femelle). Chélicères longues de $1 \mathrm{~mm}$., 20, dont 90 micra pour le doigt, 530 micra pour la tige, 500 micra pour la base (male); de $1 \mathrm{~mm}$., 57, dont 120 micra pour le doigt, 850 micra pour la tige, 600 micra pour la base (femelle); apophyse interne du doigt transversale, en croissant ì pointes situées presque au même niveau; apophyse externe normale, à dent postérieure plus forte; apophyse moyenne normale; gaine épineuse dans sa partie antérieure; simplement striée dans le reste de son étendue. Hypostome un peu lancéolé à son extrémité qui porte un grand nombre de très petites dents, les postérieures plus grosses; puis de chaque côté deux files longitudinales de 11 ou 12 dents; chacune, fortes, les dernieres squamiformes. Deux soies à la base. Palpes du mâle longs de 760 micra 230 , micra 230, micra 150 , micra 150 micra du premier au dernièr article); de la femelle, longs de 940 micra (300, micra 300 , micra 170 , micra 170 micra) le deuxième article large de 170 micra (mâle) à $\mathbf{1 7 0}$ micra (femelle). A la face dorsale des articles, surtout du premier et du deuxième et à la base dorsale du rostre au niveau de l'insertion des palpes de nombreuses soies peunéea, en séries, et des poils courts; 12 á 14 cirres terminaux. 
Pattes à hanches contigues, décroissant de la première à la quatrième paire, à bord distal renflé, cilié; à tégument hérissé de très petites épines, renforcé de granulations au bord postérieur et un peu au bord antérieur. Deuxième article tronconique, aussi large que long aux deux premières paires, plus long aux deux dernières. Les autres articles un peu aplatis de dessus en dessous. Les troisième et cinquième plus large à l'extrémité distale. Tarses cylindriques, un peu atténués à leur extrémité, pourvus le long de leur bord dorsal de trois tubercules (fig. 3a) d'autant plus marqués que la patte est plus antérieure, à peine visibles à la quatrième paire (fig. 3b). Des poils mousses et de petites épines sur tous les aticles.

Dimensions: mâle, 3 à $4 \mathrm{~mm}$. de longueur sur 2 à $3 \mathrm{~mm}$. de largeur; femelle, 5 à $7 \mathrm{~mm}$. sur 3 à $4 \mathrm{~mm}$., 5 ; nymphe, $1 \mathrm{~mm}$., 5 à $1 \mathrm{~mm}$. sur 3 $\mathrm{mm}$. à $2 \mathrm{~mm}$.

Observations-Cette description est faite d'après de nombreux individus recueillis à Guanajato (Méxique) par M. le Dr. Alf. Dugès et transmis par MM. R. Blanchard et Trouessart. (D'après G. Neumann, Revision de la famille des Ixodides. Mem. Soc. Zool. de France, Vol. X, 1897)».

\section{BIBLIOGRAPHY}

1-BARBARA' B. e DIOS R.-Contribucion al estudio de la sistematica y Biologia de los Ixodidae de la Republica Argentina. Revista del Instituto Bacteriologico del Departamento Nacional de Hygiene Vol. 1 no 3-1917 pg. 285.

2-ARAGÃO H. B.-Sobre a pretensa identidade entre O. rostratus Aragão 1911 e O. turicata Dugés 1876. Archivos da Escola Superior de Agricultura e Medicina Veterinaria, Vol. III, no 1 e 2 , 1919.

3-ARAGÃO H. B.-O. brasiliensis n. sp. Brasil Medico Anno 37 pg. 20. 1923.

4--DIOS R. e RUOPOFF R.--Sobre Ixodoidea de la Republica Argentina Revista Soc. Argentina de Biologia Vol. 6, no 9 e 10.

\section{EXPLANATION OF PLATE XXXI}

Fig. 1 -Ornithodoros rostratus, female (dorsum).

Fig. 1a-Tarsus I of $O$. rostrafus.

Fig. 1b-Tarsus IV of $O$. rostratus.

Fig. 2-Ornithodoros brasiliensis female (dorsum).

Fig. 2a-Tarsus I of $O$. brasiliensis.

Fig. 2b-Tarsus IV of $O$. brasiliensis.

Fig. 3 -Ornithodoros turicata female (dorsum).

Fig. 3a-Tarsus I of O. turicata.

Fig. $3 \mathrm{~b}-$ Tarsus IV of $O$. turicata. 